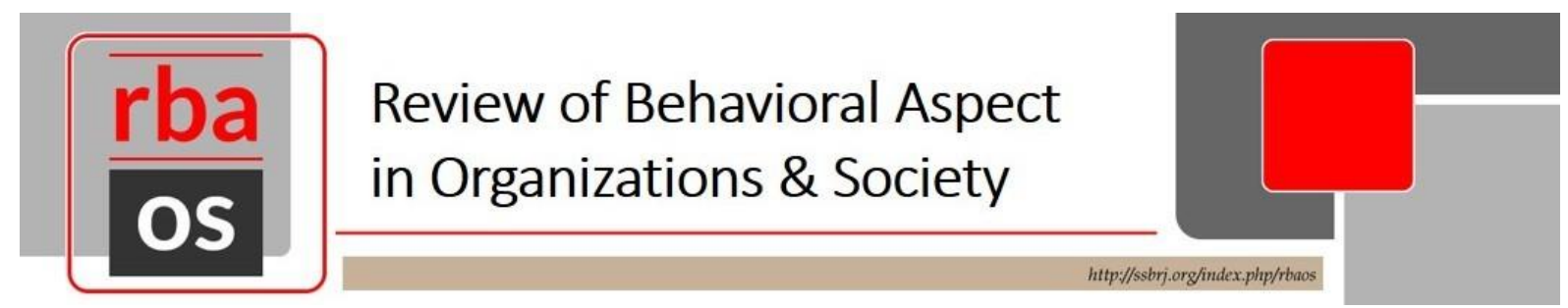

\title{
THE EFFECT OF FERTILIZER SUBSIDY ON PADDY PRODUCTION OF SMALL SCALE FARMERS: SPECIAL REFERENCE IN POLONNARUWA DISTRICTIN SRI LANKA
}

\author{
M. B. Ranathilaka, University of Peradeniya, Sri Lanka \\ I. A. J. Imbulana Arachchi, University of Peradeniya, Sri Lanka
}

\begin{abstract}
Paddy cultivation is major part in rural agriculture sector in Sri Lanka. Majority of rural sector paddy farmers are small-scale producers. According to available data paddy production sector provides livelihood opportunities for large numbers of rural population, provide rice requirement of the nation, provide inputs to other industrial sector etc.To enhance small-scale farmers living condition as well as paddy production, Sri Lankan government promotes paddy farmers to use more fertilizer for their paddy cultivation activities. Therefore, Sri Lankan government provides subsidized fertilizer to enhance both paddy production and paddy yield per acre. Last few decades paddy production and paddy yield per acre data show continues increasing trend. At the same time government expenditure on fertilizer also becomes heavy burden to national budget. There are arguments for and against to fertilizer subsidy program and its practice. This study attempts to study the effect of fertilizer subsidy on paddy production and living condition of small-scale farmers in Polonnaruwa district in Sri Lanka. The data are used to estimate an econometric model to find the relationship between paddy productivity, fertilizer subsidy, agricultural infrastructure facilities and farmers education level. The data were collected from Bubula and Raja-elagama villages in Higurakgoda divisional secretariat in Polonnaruwa district. Structured questioner was used to collect the data from 150 farmers. The results show that there is significant relationship between paddy production and dependent variables named fertilizer subsidy, agricultural infrastructure facilities and farmers education level. Especially fertilizer subsidy and paddy productivity is significant at 5 per cent level and $\mathrm{R}^{2}$ was 0.68 . This result shows that government main objective of fertilizer subsidy that improves paddy productivity has been fulfilled. At the same time, household income from paddy has also increased and it has affected their livelihoods. But poor agricultural infrastructural facilities have mitigated farmers' income. Research results and some empirical evidence have concluded that it is important to find alternative methods to select suitable and needy farmers who are eligible to get fertilizer subsidy because conducting methods of distributing have made many kinds of effects on the efficiency of resource utilization, equity of income distribution as well as government budget. Agricultural infrastructure facilities are very important for making fertilizer subsidy programs more meaningful and to have a significant effect on enhancing paddy farmers' living conditions.
\end{abstract}

Keywords: farmers, paddy cultivation, fertilizer subsidy, agricultural infrastructure. 


\section{Introduction}

After independence in Sri Lanka, successive governments have implemented various kinds of agricultural policies such as colonization programs, agricultural loans, small/medium/large irrigation projects, free extension, infrastructure facility developments, guaranteed price schemes, subsidies etc. towards the develop meet of the agriculture sector because this sector is the prime sector in the economy (Semasinghe, 2014). According to the Central Bank in Sri Lanka (2015) and Department of Census and Statistics (2015) respectively 28 per cent of labor force and 29 per cent of land are directly and indirectly engaged in agriculture and related activities but the agriculture sector's share of GDP is 9.6 percent in this year. Many research results have revealed that the low productivity of the agricultural sector is due to many reasons such as small plots of land, traditional and low quality of seeds, low amount of application and quality of fertilizer/pesticide, primitive technology, lack of working capital, low level of mechanization, traditional beliefs and culture etc. However, the role of agriculture in economic development is recognized in many ways (Lewis, 1954; Fbi and Ranish, 1964; Johnston, 1961; Mellor, 1963; Kuznates, 1964). Different to these scholars, Schumpeter (1934) mentioned the role of agricultural productivity in economic development in developing countries with the consideration of modern technology. Under this scenario Sri Lankan government has implemented various programs to increase agricultural productivity, production and income of the farming community.

Within the agriculture sector, paddy cultivation is a major part in Sri Lanka (Semasinghe, 2014). Majority of the rural sector paddy farmers are small-scale producers. According to available data paddy production sector provides livelihood opportunities for 1.8 million people among the rural population (Weerahewa et al., 2010, Wanninayaka, 2012). Until 1980's agriculture sector had been neglected even though it is the prime sector in the economic development process in Sri Lanka and agricultural land expansion, land productivity, product diversification, adoption of new technology stagnated. Fernando (1999) estimated that per capita rice consumption at 1997 was $100 \mathrm{kgs}$ (according to Department of Census and Statistics estimation per capita rice consumption was $101.13 \mathrm{~kg}$ in 2007) and annual population growth rate was 1.2, therefore 1997 rice production should be 1.8 metric tons and at 2010 it should be 2.23 metric tons. But rice production did not increase to provide enough food for 20 million people due to low level of land and labor productivity in this sector and it badly affected rural people because majority of them earned their main income by engaging in agriculture and related activities (The World Bank Group 2003, Semasinghe, 2014). At the same time 15.7 per cent of rural people were under poverty line (Department of Census and Statistics 2006/2007). Many research works identified that land is a constant factor in Sri Lanka and therefore productivity increase in agriculture is a main instrument for poverty reduction in the rural sector (Gunadasa, 1998, The World Bank Group 2003). In this scenario, to enhance small-scale farmers living condition as well as per acre of paddy production, Sri Lankan government promotes paddy farmers to use more modern fertilizers for their paddy cultivation activities through providing subsidized fertilizers under the objectives of enhancing both paddy production and paddy yield per acre. Therefore, the data of last few decades' paddy production and paddy yield per acre shows a continue increasing trend (Weerahewa et al., 2010). At the same time government expenditure on fertilizer has also become a heavy burden to national budget (Weerahewa et al., 2010). However, there are arguments for and against the fertilizer subsidy program and its practice. Thus, the main objective of the government is to increase the agriculture sector contribution to GDP. It will lead to protect national food security, increase calorie consumption and improve people's health, reduce food import bill and uplift the living standard of the nation. This study attempts to study the effect of fertilizer subsidy on paddy production and living condition of 
small scale farmers in Polonnaruwa district in Sri Lanka. The data are used to estimate an econometric model to find the relationship between paddy productivity, fertilizer subsidy, agricultural infrastructure facilities and farmers' education level. The data were collected from Bubula and Raja-elagama villages in Higurakgoda divisional secretariat in Polonnaruwa district in Yala season 2014 and Maha season 2014/2015. A structured questioner was used to collect the data from 150 farmers.

\section{Background of the Study}

Salunkhe and Deshmush (2012) noted that the agricultural subsidies play an important role in the agriculture sector in each and every country. According to historical evidence the fertilizer subsidy program was started in 1962 in Sri Lanka parallel with the Green Revolution. During the period from 1962 to 1989 the subsidy was provided to primarily paddy farmers for all three main types of fertilizers namely nitrogen $(\mathrm{N})$, phosphorus $(\mathrm{P})$, and potassium (K) but the fertilizer subsidy was not provided for the period from 1990 to 1994. However, it was again started to be given from 1994 for only urea and it had again been extended to provide three types of fertilizer under the price Rs. 350 (US\$3.07) per $50 \mathrm{~kg}$ bag of fertilizer in 2005 (Weerahewa et al., 2010). In 1998 the fertilizer subsidy expenditure was Rs. 2,152 million and it increased up to Rs. 26,937 million in 2009. It was respectively 0.80 per cent to 2.24 per cent on considering years from total government expenditure (Central Banks Reports 1999 and 2010). At present the fertilizer subsidy has increased up to Rs. 49,571 million and it was 2.29 per cent from the total government expenditure (Central Bank 2015). Sri Lanka is self-sufficient in rice with 20 per cent excess paddy production over consumption requirements in 2015 (Central Bank 2015). The total paddy production marked its highest at 4.8 million MT in 2015 compared with the prior highest ever recorded paddy production of 1.9 million MT in Yala season and Maha season production of 2.9 million MT in 2014/2015. According to the Central Bank (2015) in Sri Lanka paddy production increase was due to few reasons such as increased extent of cultivated land, increase in paddy yield and improved paddy harvest resulting from favorable weather conditions prevailed in 2015 . In addition to the above factors, it effected several government programmes, such as mainly fertilizer subsidy, guaranteed price for paddy, cultivation loans at concessionary interest rates and extension services. 
Table 1. Fertilizer Subsidy and Total Paddy Production in Sri Lanka

\begin{tabular}{|c|c|c|c|c|c|}
\hline Year & $\begin{array}{l}\text { Fertilizer } \\
\text { Subsidy } \\
\text { Million }\end{array}$ & Rs. & $\begin{array}{l}\text { Fertilizer Subsidy } \\
\text { as Percentage of } \\
\text { GDP }\end{array}$ & $\begin{array}{l}\text { Total } \\
\text { Production } \\
(\cdot 000)\end{array}$ & $\begin{array}{r}\text { Paddy } \\
\text { MT }\end{array}$ \\
\hline 1996 & & 1,500 & 0.60 & & 2,061 \\
\hline 1997 & & 1,894 & 0.70 & & 2,239 \\
\hline 1998 & & 2,152 & 0.80 & & 2,692 \\
\hline 1999 & & 1,390 & 0.50 & & 2,857 \\
\hline 2000 & & 1,733 & 0.52 & & 2,860 \\
\hline 2001 & & 3,650 & 0.94 & & 2,695 \\
\hline 2002 & & 2,448 & 0.61 & & 2,860 \\
\hline 2003 & & 2,191 & 0.52 & & 3,067 \\
\hline 2004 & & 3,572 & 0.75 & & 2,628 \\
\hline 2005 & & 6,846 & 1.17 & & 3,246 \\
\hline 2006 & & 11,867 & 1.66 & & 2,342 \\
\hline 2007 & & 11,000 & 1.31 & & 3,131 \\
\hline 2008 & & 26,450 & 2.66 & & 3,875 \\
\hline 2009 & & 26,937 & 2.24 & & 3,652 \\
\hline 2010 & & 22,000 & 2.10 & & 4,301 \\
\hline 2011 & & 42,000 & 2.20 & & 3,894 \\
\hline 2012 & & 35,000 & 2.40 & & 3,846 \\
\hline 2013 & & 18,000 & 1.20 & & 4,621 \\
\hline 2014 & & 35,000 & 1.80 & & 3,381 \\
\hline 2015 & & 49,571 & 1.70 & & 4,819 \\
\hline
\end{tabular}

Sources: Central Bank, Sri Lanka

As mentioned earlier, paddy production is a major source of rural livelihoods, therefore successive governments have paid great attention providing short term and long-term investment to further improve this sector. The policies, programs, and strategies to increase paddy production have included large-scale and small-scale irrigation projects joined with land development and settlement schemes, free provision of irrigation water, provision of concessionary credit, expand extension services, high yielding seeds at concessionary rates, guaranteed output and input prices and fertilizer subsidy. Among these programs fertilizer subsidy program is the longest lasting, most expensive, with management difficulties and a politically and socially sensitive program. Further, under this program the Department of Agriculture (DA) has provided suitable application of fertilizer amount per acre and it has recommended the quality of the fertilizer too. However, a large proportion of fertilizer has been imported and an unexpected side effect image was evident in many parts of the country due to quality and over application of the fertilizer even though DA recommended and promoted the quality and amount of fertilizer application. At the same time, majority of paddy farmers in Sri Lanka are small land holders of less than five acres under their control but the fertilizer subsidy has been provided considering the extent of paddy land the farmer owns which is mentioned in a written document. Some farmers get fertilizer subsidy without cultivating any paddy land in a particular season. Further, due to lack of strong distribution channels in government sector, private sector has a very strong control in the fertilizer market in Sri Lanka.

There are arguments for and against regarding fertilizer subsidy in Sri Lanka. Fertilizer subsidy given by many government agricultural development programs has increased paddy production (Bandara and Jayasuriya, 2009; Jayawickrama and Sudarshani, 2010; Weerahewa 
et al., 2010). Many elected governments in Sri Lanka have implemented fertilizer subsidy not only to increase paddy production but also to compensate the farmers who are marginalized or have got a negative impact from some other policies that these governments have implemented (Ekanayake, 2006). It is revealed that if fertilizer increases by one per cent, national rice production increases by 0.109 per cent (Herath et al., 2003). However, fertilizer subsidy alone cannot provide expected results without suitable seeds which are more responsive for the fertilizer (Kikuchi and Aluvihare, 1990). According to empirical evidence, Sri Lankan government's fertilizer subsidy program has helped to enhance paddy production, paddy productivity and finally expects the country to achieve self-sufficiency in paddy (Abeygunawardhana and Pope, 1986; Yamaguchi and Sankar, 2006; Andersen, 2010). Compared with other countries Sri Lankan government allocates a very large sum of money from the budget for the fertilizer subsidy program (Wijetunge et al., 2008). Therefore, it can be identified that the main objective of this program isto uplift the country up to selfsufficient level of paddy. However, Ekanayake (2006) argued that fertilizer subsidy in Sri Lanka is not the key determinant of the use of fertilizer in paddy cultivation, especially in the short-run.

Some researchers noted that fertilizer subsidy reduced fertility of soil and it caused to increase costs of paddy production (Ekanayake, 2006) but some researchers noted that fertilizer subsidy increased profit of paddy farmers due to increase of paddy productivity effect from fertilizer subsidy (Jayawardana and Weerasena, 2000; Weerahewa et al., 2010). However, many empirical research works concluded that fertilizer application on cultivation activities had a directeffect on the increase of productivity (Griliches, 1958; Heady and Yeh, 1959; Burrell, 1982). Therefore, providing fertilizer subsidy for poor farmers will lead to improve their living standard and reduce their burden on variable costs (Andersen, 2010; Semasinghe, 2014; Herath et al., 2003). Further it will help to increase food supply for the nation (Ahmed, 1978; Ramli et al., 2012).

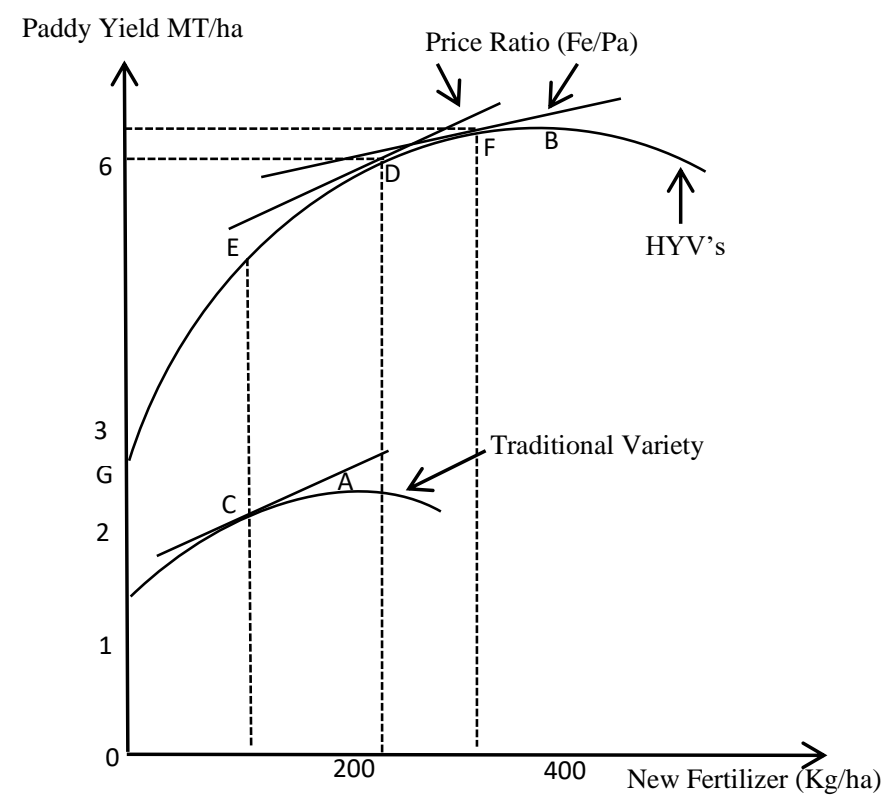

Figure 1. Outputs and fertilizer use with and without high yielding varieties

Fertilizer subsidy is expected to increase production, productivity, reduce burden of farmers, increase farmers' income etc. (Wicramasinghe et al., 2009; Weerahewa et al., 2012). However, as mentioned earlier it is debatable whether fertilizer subsidy will have an effect on 
resource allocation efficiency in agricultural sector and its effect on national budget. Further Ellis (1992) noted that fertilizer alone does not have an effect on the increase of productivity in the agriculture sector. The amount of the fertilizer increments and crop yield increment corresponding with it may both be only comparatively small unless new crop varieties are developed which are more responsive than traditional varieties of fertilizer application. Therefore, new seeds, technology, machinery and farm management are also the most important factors. Figure 1 shows the efficiency of fertilizer with traditional seed varieties and high yielding varieties and result of change fertilizer price. It concludes that fertilizer subsidy bind with new technology (HYV's) generates higher results compared with fertilizer with HYV's and fertilizer with traditional varieties. But if fertilizer price ration is changed beyond point $\mathrm{B}$ noted in figure 1 , it can be seen as an ineffective resource allocation in agriculture sector.

\section{Methodology and Data Analysis}

At the data analysis, it is expected to identify the relationship between government fertilizer subsidy policy on paddy productivity using field research data. Further, attention is paid on the effect of farmers' education level and infrastructure facilities for farm productivity. In this purpose multiple regression model is used which was developed by $\mathrm{Hu}$ and Antle (1993) to explain the relationship between agricultural policy and paddy productivity using cross sectional countries data. Their model was moderated according to the purpose of this research work. The production model (1) specifies for farm output (Q) to be a function of Labor (L), Land (A) Machinery (M) and Fertilizer (F) inputs per farm. Using model 1, it can be derived total factor productivity (TFP). The proxy variable was used in $\mathrm{Hu}$ and Antle (1993) to indicate the degree of subsidization of agricultural sector is the aggregate nominal protection coefficient (NPC). The policy model specifies the NPC (noted as function 2) to be a function of output (Q), income per capita (I) and agricultural land per capita (C). Finally, to estimate the relationship between government policy and productivity TFP function is used. In this function $\mathrm{b}_{0}$ is paddy productivity, NPC is fertilizer subsidy, $\mathrm{N}$ is infrastructure facilities and $\mathrm{E}$ is farmers' education. In this function due to lack of available date on government subsidies, fertilizer subsidy is only considered as NPC.

$$
\begin{aligned}
& \mathrm{Q}=\mathrm{b}_{0} \mathrm{~L}^{\mathrm{b} 1} \mathrm{~A}^{\mathrm{b} 2} \mathrm{M}^{\mathrm{b} 3} \mathrm{~F}^{\mathrm{b} 4} \mathrm{e}^{\mathrm{u}} \ldots \ldots \ldots \ldots \ldots . . . \\
& \mathrm{TFP}=\mathrm{b}_{0}=\mathrm{Q} / \mathrm{L}^{\mathrm{b} 1} \mathrm{~A}^{\mathrm{b} 2} \mathrm{M}^{\mathrm{b} 3} \mathrm{~F}^{\mathrm{b} 4} \mathrm{e}^{\mathrm{u}} \\
& \mathrm{NPC}=\mathrm{aQ}{ }^{\mathrm{a} 1} \mathrm{I}^{\mathrm{a} 2} \mathrm{C}^{\mathrm{a} 3} \mathrm{e}^{\mathrm{v}} \ldots \ldots \ldots \ldots \ldots \ldots \ldots \ldots \\
& \mathrm{b}_{0}=\mathrm{b}_{01}+\mathrm{b}_{02}(\mathrm{NPC})+\mathrm{b}_{03}(\mathrm{~N})+\mathrm{b}_{04}(\mathrm{E})
\end{aligned}
$$

However, farmers' education and agricultural infrastructure facilities are qualitative data. Therefore, model 3 was modified as mentioned in model 4 using Dummy variables on behalf of agricultural infrastructure and farmer's education. Agricultural infrastructure facilities were divided into 5 categories such as transport facilities $\left(D_{1}\right)$, storage $\left(D_{2}\right)$, institutional marketing facilities $\left(\mathrm{D}_{3}\right)$, institutional credit facilities $\left(\mathrm{D}_{4}\right)$ and irrigated water supply $\left(\mathrm{D}_{5}\right)$. Farmers' education level was divided into 5 categories too such as not attended school $\left(\mathrm{D}_{6}\right)$, attended school from grade 1 to $5\left(D_{7}\right)$, attended school from grade 6 to $10\left(D_{8}\right)$, attended school from grade 11 to $12\left(\mathrm{D}_{9}\right)$ and more than grade12 $\left(\mathrm{D}_{10}\right)$.

$$
\begin{aligned}
& \left.\left.\left.\left.\mathrm{b}_{0}=\mathrm{b}_{01}+\mathrm{b}_{02}(\mathrm{NPC})+\mathrm{b}_{03}\left(\mathrm{D}_{1}\right)\right)+\mathrm{b}_{04}\left(\mathrm{D}_{2}\right)\right)+\mathrm{b}_{05}\left(\mathrm{D}_{3}\right)\right)+\mathrm{b}_{06}\left(\mathrm{D}_{4}\right)\right)+\mathrm{b}_{07}\left(\mathrm{D}_{5}\right) \\
& \left.\left.\left.+\mathrm{b}_{08}\left(\mathrm{D}_{6}\right)\right)+\mathrm{b}_{09}\left(\mathrm{D}_{7}\right)\right)+\mathrm{b}_{010}\left(\mathrm{D}_{8}\right)\right)+\mathrm{b}_{01}\left(\mathrm{D}_{9}\right)+\mathrm{b}_{012}\left(\mathrm{D}_{10}\right) \ldots \ldots \ldots \ldots \ldots \ldots \ldots \ldots \ldots \ldots \ldots \ldots \ldots \ldots \ldots \ldots \ldots \ldots
\end{aligned}
$$




\section{Results and Discussion}

Many research works have proved that there are positive relationships between total paddy production and input applications (Dayal, 1984; Huffman and Evenson, 1992; Block, 1994). Further they mentioned that extent of land, mechanization, fertilizer, high yielding seeds varieties etc. are most important inputs which are very highly response to total production. Green revolution in 1960's noted significant improvement in agriculture sector by the development of HYV's and chemical fertilizer which are highly response to each, others. Through the favorable effect on crop yields, even subsistence farmers stand to gain from adopting HYV varieties. They are able to produce more for their own consumption with the same effort. Accordingly, methodology model 1.1 is developed to measure the relationship between total paddy production and inputs. The results are depicted in table 1.2. The results imply that there are strong positive relationships between total paddy production and inputs such as land, labor and machinery and significant relationship at one per cent confidence level. These results are more parallel with the literature that are mentioned above. Overall regression significance at 5 per cent confident level and $\mathrm{R}^{2}$ which is suitability of the models very high (0.9638). It implies that increase or developing these factors will cause to increase total paddy productivity and vice versa. It meant that 96 per cent of this model is confidence to explain the change of paddy production in this area. Further it is discussed above that there is a positive relationship between paddy production and fertilizer. The research result shows that there is a negative relationship between these two factors which opposite of literature has showed but it is not significant. However, over fertilizer application and long-term fertilizer application reduce fertility of soil but research has not revealed clear evidences to prove over fertilizer application in the area. Therefore, it can be inferred due to sampling and nonsampling errors.

Table 2. Results of the model 1

\begin{tabular}{lrr}
\hline \multicolumn{1}{c}{ Variables } & \multicolumn{2}{c}{$\mathrm{R}^{2}=0.9638$} \\
\hline Cons & 3.955327 & $\mathrm{P}>(\mathrm{t})$ \\
Land $(\mathrm{A})$ & 0.7677513 & 0.000 \\
Labor (L) & 0.2073365 & 0.000 \\
Machinery (M) & 0.2432719 & 0.000 \\
Fertilizer (F) & -0.5000906 & 0.000 \\
\hline Sourtient & & 0.302 \\
\hline
\end{tabular}

Sources: Field data analysis

Regression results of model 2 which explains the relationship government policy and some factors such as total paddy production, farmer income and land ownership are depicted in table 3. In this model, it is heavily concerned whether above factors will have on effect on fertilizer subsidy which government policy implication. According to the results of regression model $2, \mathrm{R}^{2}$ is 0.9638 and over-role regression model significance at one present confidence level. It implies that there is a very strong relationship between fertilizer subsidy and the factors named as total paddy production, farmer income and land ownership. However, except ownership of land per capita which is significant at one per cent confidence level and positive relationship, individually other factors are not significant. Further, income per capita shows a negative relationship with fertilizer subsidy while output shows a positive relationship. This result implies that government has not considered farmers income level when they have been given fertilizer subsidy. The ownership of land and size of land are the determining factors of fertilize subsidy and amount of fertilizer subsidy. Therefore, rich land owners as well as poor peasant farmers enjoy equally with government fertilizer subsidy 
policy in Sri Lanka. When size of land increase it will provide extra benefit to farmers because government recommended fertilizer formula related to per acre. Per capita land ownership and fertilizer subsidy significant at one per cent confidence level prove this strong relationship. In traditional agriculture it might be expected to show constant returns to scale but differences in output between farmers are broadly proportional to the corresponding differences in the inputs of both land and fertilize. However, the constant returns hypothesis is subject to two important assumptions: first, the assumption of factor divisibility and second, the assumption of common factor prices regardless of farm size. This situation is not shown in these results.

Table 3. Results of the model 2

\begin{tabular}{lrr}
\hline & & $\mathrm{R}^{2}=0.9638$ \\
\hline Variables & Coefficient & $\mathrm{P}>(\mathrm{t})$ \\
\hline Cons & 3228.67 & 0.159 \\
Output $(\mathrm{Q})$ & 0.9139685 & 0.160 \\
income per capita (I) & -0.0184886 & 0.416 \\
agricultural land per capita (C) & 7642.183 & 0.000 \\
\hline
\end{tabular}

Sources: Field data analysis

Table 4 shows the results derived from model 4. As mentioned earlier in this model there are three independent variables named fertilizer subsidy, infrastructure facilities and farmers education level. This model is significant at 5 per cent level with $\mathrm{R}^{2}$ is 0.68 . It meant that above mentioned variables have considerable an effect on paddy productivity. According to regression data, it can be seen that paddy production has increased parallel with fertilizer subsidy increases. The relationship with paddy production and fertilizer subsidy is significant at 5 per cent confident level. This positive relationship is proved by paddy production data from last 2 decades in Sri Lanka. Data shows that paddy production in Sri Lanka has increased by 2,061 MT in 1996 to 4,819 MT in 2015. However, as discussed earlier, paddy product does not depend on only fertilizer but also other factors such as infrastructure facilities, farmers' education level etc. The model 3 considers infrastructure facilities and farmers' education level. Under the infrastructure facilities, transport facilities, storage facilities, institutional facilities, institutional credit facilities and irrigated water supply are considered. According to the data, this factor was not significant and transport facilities and irrigated water supply dropped the function. At the same time, institutional marketing facilities show negative relationship. Infrastructure facilities in these areas vary due to many reasons. Irrigation water has been supplied for all farmers without any discrimination because these farmers are under Girithale water tank. Therefore, we cannot find any differences in water supply. There are no state storage facilities in these areas. Farmers have sold their paddy product just after harvest. If they have these facilities, they can retain some amount of their paddy products and sell at off season when price level goes high. It might encourage farmers to engage agriculture activities as well as increase paddy productivity. There are no proper institutional marketing facilities in these areas accept agrarian service department and paddy marketing board which purchases less than 10 per cent of total paddy production under a government guaranteed price scheme. But farmers have to waiting long queues to hand over paddy and wait a few months to take their money. Further, farmers have to fulfill many conditions such as moisture level of paddy, higher standard of paddy etc. Therefore, farmers prefer to sell their paddy harvest directly to private traders under low prices. These situations are a hinder for the increase paddy production as well as keep farmers living condition below the expected level. 
Table 4: Results of the model 4

\begin{tabular}{lrr}
\hline & & $\mathrm{R}^{2}=0.68099$ \\
\hline Variables & Coefficient & $\mathrm{P}>(\mathrm{t})$ value \\
\hline Cons & 8.130393 & 0.000 \\
lnNPC & 0.078708 & 0.033 \\
$\mathrm{D}_{1}$ (transport facilities) & dropped & - \\
$\mathrm{D}_{2}$ (storage) & 0.034392 & 0.284 \\
$\mathrm{D}_{3}$ (institutional marketing facilities) & -0.00480 & 0.897 \\
$\mathrm{D}_{4}$ (institutional credit facilities) & 0.01104 & 0.737 \\
$\mathrm{D}_{5}$ (irrigated water supply) & Dropped & - \\
$\mathrm{D}_{6}$ (not attended to school) & -0.34423 & 0.002 \\
$\mathrm{D}_{7}$ (attended school from grade 1 to 5) & -0.165041 & 0.001 \\
$\mathrm{D}_{8}$ (attended school from grade 6 to 10) & -0.566454 & 0.237 \\
$\mathrm{D}_{9}$ (attended school from grade 11 to 12) & 0.124381 & 0.020 \\
$\mathrm{D}_{10}$ (more than grade 12) & Dropped & - \\
\hline $\mathrm{S}$ & &
\end{tabular}

Sources: Field data analysis

The factor which affects paddy productivity, farmers' education level was divided into 5 categories as mentioned earlier and results are depicted in table 4. According to results it shows that farmers who did not attend school and attended school to less than grade five are significant at one per cent confidence level with negative relationship. It implies that paddy productivity cannot decrease by providing fertilizer subsidy without providing enough education. Specially, when farmers use new fertilizer varieties, they will be given necessary extension with regards the way of use, amount of application and suitable time of application. If they cannot understand this extension properly it will lead to create a number of side effects for both human and environment and reduce paddy productivity as well. The farmers who attended up to grade 12 show positive and significant relationship with paddy production. It can be believed that these farmers have enough capacity to understand the use of new fertilizer effectively and efficiently. Further, they can understand side effects and environmental damage compared with lower educated farmers. Most of these farmers get information and knowledge related to market prices, new verities of seed, pesticides and fertilizer through deferent kinds of sources as well as they do inventions and innovations related to paddy cultivation. Thus, education helps farmers to improve their living condition through increase paddy productivity.

\section{Conclusion}

The main objective of the study is to find the relationship between paddy productivity, fertilizer subsidy, agricultural infrastructure facilities and farmers education level. The results conclude that government fertilizer subsidy policy is significantly and positively related with paddy productivity. It means that government policy leads to increase paddy productivity in these areas. Majority of inhabitants of Sri Lanka live in rural sector and their main income generates from agriculture and related activities. Therefore, increase of paddy productivity quantitatively and qualitatively positively and directly affects the uplift of farmers living conditions. According to data, majority of poor people live in rural sector and their 
affordability for fertilizer is very low. Subsidized price of fertilizer leads to motivate farmers to apply them in the paddy field and create surplus to sale in the market.

According to field observations, before and after fertilizer subsidy, motivation for use fertilizer positively changed. Specially, before fertilizer subsidy farmers' costs of production was very high and prevailing market price did not cover their production costs. Before fertilizer subsidy they had spent Rs.5,300 per 50kg of fertilizer bag. Therefore, majority of farmers did not use new fertilizer even though it is an essential input to increase paddy productivity per acre. Under fertilizer subsidy the same fertilizer bag has been given under Rs. 300, most of farmers apply fertilizer and reduce their production costs while they increase productivity of paddy per acre. Further it helps to change motivation and attitudes on agriculture as well.

This is the economic rate of input usage at the new lower price level and it would be substantially increased compared with the rate justified by existing technology making negative social benefit. On the other hand, it can be argued that changes in factor prices give guidance to discover improved technology regarding types of technological advance with the best market prospects. It emphasizes technological or research input and the discovery of innovations which broaden the scope for factor substitution in response to the price change of fertilizer. But it is believed that technical change in agriculture sector tends to be impeded by various kinds of institutional barriers. In particular, Sri Lanka generally lacks adequate agricultural research institutions to foster the discovery and application of new scientific and technical knowledge. Institutional innovation is consequently, needed to break this bottleneck. Therefore, technical innovation and institutional innovation are complementary link with government subsidy policy. The farmers can normally be expected to increase fertilizer inputs in response to a decline in the fertilizer and crop price ratio due to fertilizer subsidy. But the amount of the fertilizer increments and crop yield increment corresponding with it may both be only comparatively small unless new crop varieties are developed which are more responsive than traditional varieties of fertilizer application for example high yielding varieties (HYV's). Therefore, paddy productivity change not only depends on fertilizer but also on some other factors mentioned above.

Further, infrastructure facilities and farmers' education level show a considerable relationship with paddy productivity. Under infrastructure, farmers have not been provided institutional storage facilities, but few farmers have their own storage with poor conditions. Therefore, majority of farmers' sell their paddy production just after harvest under prevailing prices even though low. It is concluded that if farmers have enough storage facilities it will help them to sell their paddy production under higher prices at the off-season. Further, it can be concluded that institutional marketing facilities and institutional credit facilities do not help to increase their paddy productivity and income. However, education is a very important factor which shows positive and significant relationship. Farmers' poor education level decrease government objective through fertilizer subsidy policy. Improvement of farmers' education level will help to get more results from government fertilizer subsidy policy compared with present results.

Finally, results show that fertilizer subsidy alone provides marginal impact on increase paddy productivity. Therefore, it is important to consider whether to continue fertilizer subsidy or change according to the necessity. However, small scale farmers get benefit from this policy because it helps them to reduce their cultivation costs even though it does not increase productivity. Therefore, to re-adjust fertilizer subsidy program, it should be considered same 
factors such as farmers' income level and extra income sources, land augmenting activities, uncultivated land use for re-cultivation etc. Thus, it can be concluded that it is important to use alternative policies which are suitable to increase paddy production while gradually reducing fertilizer subsidy.

\section{References}

Abeygunawardhana, P. \& C. A. Pope. (1986). Impacts of price and yield variation on profitability of management plans of subsistence farmers in Sri Lanka. Agricultural Administration, 22, 197-204.

Ahmed, R. (1978). Price support versus fertilizer subsidy for increasing rice production in bangladesh. The Bangladesh Development Studies, 119-138.

Aluwihare, P. B. (1991). Irrigation investment trends in Sri Lanka: New construction and beyond. Colombo, Sri Lanka: Irrigation Management Institute.

Andersen, P.P. (2010, November 16). The costs and benefits of fertilizer subsidies: An illustration from Sri Lanka. Retrieved from http://smkern.com/pinstrup/wordpress/? $\mathrm{p}=101$.

Block, S. A. (1994). A new view of agricultural productivity in sub-Saharan Africa. American Journal of Agricultural Economics, 76(3), 619-624.

Burrell, A. (1989). The demand for fertiliser in the United Kingdom. Journal of Agricultural Economics, 40(1), 1-20.

Bandara, J. \& S. Jayasuriya. (2009). Distortions to agricultural incentives in Asia, Sri Lanka, in K Anderson \& W Martin (eds). Washington DC, USA: The World Bank.

Central Bank of Sri Lanka. Annual Reports (various issues). Colombo: Central Bank of Sri Lank, Sri Lanka.

Dayal, E. (1984). Agricultural productivity in India: a spatial analysis. Annals of the Association of American Geographers, 74(1), 98-123.

Department of Census and Statistics. (2007). Census of agriculture 2002, agriculture and environmental statistics division. Department of Census and Statistics, Colombo, Sri Lanka. Retrieved from http://www.statistics.gov.lk/agriculture/AGC2002/AGC2002. htm

Ekanayake, H. K. J. (2009). The impact of fertilizer subsidy in paddy cultivation. Staff Studies, Central Bank of Sri Lanka, 36(1\&2), 73-96.

Ellis, F. (1992). Agricultural policies in developing countries. Cambridge, New York: Cambridge University Press.

Fbi, J. C. H., \& Ranis, G. (1964). Development of the labor surplus economy: theory and policy. Homewood.

Fernando, G. (1999). Overview: Economic Review, People's Bank. Colombo, Sri Lanka.

Gunadasa, J. M. (1998). The role of multi-purpose cooperative societies in avoiding future social problems in Sri Lanka. National Development through Cooperative movement, Ministry of Cooperative Development, Information Technology Center, Sri Lanka School of Cooperative, Polgolla, 69-91.

Griliches, Z. (1958). The national or regional demand for total fertilizer or nutrient application on all crops. Western Journal of Agricultural Economic, 7(2).

Heady, E. O., \& Yeh, M. H. (1959). National and regional demand functions for fertilizer. Journal of Farm Economics, 41(2), 332-348.

Huffman, W. E., \& Evenson, R. E. (1992). Contributions of public and private science and technology to US agricultural productivity. American Journal of Agricultural Economics, 74(3), 751-756. 
Herath, H. M. K. V., Gunawardena, E. R. N., \& Wickramasinghe, W. M. A. D. B. (2015). The impact of "Kethata Aruna" fertilizer subsidy programme on fertilizer use and paddy production in Sri Lanka. Tropical Agricultural Research, 25(1),14-26.

Hu, F. \& Antle, J.M. (1993). Agriculture policy and productivity: International evidence, applied economic perspectives and policy. Oxford Journals, 15(3), 495-505.

Jayawickrama, A. \& W.M.G.T.S. Sudarshani, (2010). The impact of fertilizer subsidy on agricultural production. Prathimana-06, Sociology Research Forum, University of Ruhuna.

Jayawardana, S.S.B.G.D. \& Weerasena, L.A. (2000). Crop diversification in Sri Lanka. Department of Agriculture, University of Peradeniya, Sri Lanka.

Johnston, B. F., \& Mellor, J. W. (1961). The role of agriculture in economic development. The American Economic Review, 51(4), 566-593.

Kuznets, S. (1964). Economic Growth and the Contribution of Agriculture. In C. K. Eicher \& L.W. Witt (Eds.) Agriculture in economic development. New York: McGraw-Hill.

Lewis, W. A. (1954). Economic development with unlimited supplies of labour. The manchester school, 22(2), 139-191.

Mellor, J. W. (1963). The use and productivity of farm family labor in early stages of agricultural development. Journal of Farm Economics, 45(3), 517-534.

Ramli, N. N., Shamsudin, M. N., Mohamed, Z., \& Radam, A. (2012). The impact of fertilizer subsidy on Malaysia paddy/rice industry using a system dynamics approach. International Journal of Social Science and Humanity, 2(3), 213-219.

Salunkhe, H. A., \& Deshmush, B. B. (2012). The overview of government subsidies to agriculture sector in India. IOSR Journal of Agriculture and Veterinary Science, 1(5), 43-47.

Economic and social cost of fertilizer subsidy on paddy farming in Sri Lanka \& M. Semasinghe. (2014). Economic and social cost of fertilizer subsidy on paddy farming in Sri Lanka. International Journal of Science and Research, 3(10).

Semasinghe, W. M. (2014). Economic and social cost of fertilizer subsidy on paddy farming in Sri Lanka. International Journal of Science and Research, 3(10).

Thanawala, K. (2006). Schumpeter's theory of economic development and development economics. Review of Social Economy, 52(4), 353-363. http://dx.doi.org?10.1080/758523229.

The World Bank Group. (2003). Sri lanka: Promoting agricultural rural non-farm sector growth. Rural Development Unit, South Asia Region, World Bank, Vol. I and II.

Weerahewa, J., S.S., Kodithuwakku \& Ariyawardana, A. (2010). The fertilizer subsidy program in Sri Lanka, case study no 7-11 of the programs: food policy for developing countries: the role of government in the global food systems. New York: Cornell University.

Wijetunga, W. M. L. K., Thiruchelvam, S., \& Balamurali, N. (2008). Impact of "KETHATA ARUNA" fertilizer subsidy on paddy production in Minipe Scheme. In Second Annual Research Forum of the Sri Lanka Agricultural Economics Association, October (Vol. 3).

Wickramasinghe, W., Samarasinha, G., \& Epasinghe, S. (2009). Fertilizer policy on paddy farming: Evaluation of subsidy program 2005. Hector Kobbekaduwa Agrarian Research and Training Institute, Colombo. Unpublished report.

Yamaguchi, M., \& Sanker, S. (2007). Growth accounting for sri lanka's agriculture with special reference to fertilizer and nonagricultural prices: do policy reforms affect agricultural development?. The Developing Economies, 45(2), 194-219. 